\title{
The Impacts of Tour de Flores Event for Tourism Development in West Manggarai, Nusa Tenggara Timur
}

\author{
Febi Marice Erni Utan ${ }^{1 *}$, Agustinus Sri Wahyudi ${ }^{2}$, Fetty Asmaniati ${ }^{3}$ \\ 1,3 Sekolah Tinggi Pariwisata Trisakti \\ 2Sekolah Tinggi Ilmu Ekonomi Trisakti \\ *feby.utan@gmail.com
}

\begin{abstract}
This research aims to analyze the impact of Tour de Flores event for tourism development in economic, social and environmental aspects. The 100 respondents are randomly selected from local communities with Slovin formula. Multiple linear regression model is used to analyze the impact of Tour de Flores event on tourism development in West Manggarai. The results of this research have partially proven that tourism development in economic area has a positive impact which is proved by t-test where the value of $t$ count $>t$ table $(3,209>$ 1,985). Positive impact has shown in environmental as well where the value of $\mathrm{t}$ count $>\mathrm{t}$ table $(2,449>1,985)$ This results means that both variables have a positive impact or $\mathrm{H} 0$ is rejected. While the negative relationship or $\mathrm{H} 0$ accepted is the impact of tourism development from social where the value of $\mathrm{t}$ count $<\mathrm{t}$ table $(0,314$ $<1,985)$, it means that Tour de Flores event has no social impact on tourism development. Simultaneously, the results of this research show that the three independent variables; tourism development have a positive impact on economic, social and environmental. It is shown by $\mathrm{F}$ test that where value of $\mathrm{F}$ count $>\mathrm{F}$ table $(86,723>2,699)$ so that $\mathrm{H} 0$ is rejected.
\end{abstract}

Keywords: tourism development, tourism impact, economic impact, social impact, environmental impact

TRJ Tourism Research Journal, Volume 1 (1), 2017 
The Impacts of Tour de Flores Event for Tourism Development in West

Manggarai, Nusa Tenggara Timur

\section{A. Introduction}

Tour de Flores (TDF) is an annual tourism event in Flores, Nusa Tenggara Timor. This event serves as a competition for international road bikers under the regulation of Union Cyclist International (UCI). In addition to a competition, this event also tries to introduce tourism in Flores internationally. To make this event a success, there should be a strong cooperation among the government, local community and related institutions. For example, the government through Ministry of Tourism collaborates with other related ministry, and private parties to make sure that this event gives its best impression and satisfaction for the participants, tourists and the local community. Not only does this event serve as a way to promote tourism sector, but it also supports city branding program of Flores and Nusa Tenggara Timor in as a New Tourism Territory. Eventually, this annual program is expected to increase tourist visits and local revenue.

Below are the purposes of Tour de Flores as expressed by the Chairman of the program:

1. To promote tourism in Flores.

2. To introduce Labuan Bajo as a tourist destination priority.

3. To attract foreigners to visit Flores through international Cycling event.

4. To encourage social, economic and environmental impacts resulting from the development of Western Manggarai tourism.

To support this program, Nusa Tenggara Timor (NT'T) government has allocated 3 billion rupiahs to run this activity. Besides, each regency and district also contributed to finance this activity (Voice Updates: 2016). The multiplier effect of this activity is expected to improve the economy of the surrounding community. Given the facts above, TDF also serves as a motivating factor for the government and local people to preserve the natural and cultural attractions. By keeping the natural and cultural attractions, local economy is expected to raise which results in people's welfare. Since this event has the potential to introduce tourism in Flores abroad and is also a long-term investment from the local government, TDF is assumed to have a positive impact on the western Manggarai community so that it can affect the development of tourism in western Manggarai.

TDF should be able to give benefit and positive impacts for the local people. Those impacts will influence people's perception and also behavior on 
The Impacts of Tour de Flores Event for Tourism Development in West Manggarai, Nusa Tenggara Timur

tourism development in their areas. Based on the above background, the research focuses on the following problems:

1) Is there any economic impact of TDF on tourism development in West Manggarai?

2) Is there any social impact of TDF on tourism development in West Manggarai?

3) Is there any environmental impact of TDF on tourism development in West Manggarai?

4) To what extent does economy, social, and environment impact of TDF affect the tourism development in West Manggarai?

\section{B. Literature Review}

UNWTO (United Nation World Tourism Organization), defines tourism as activities of persons traveling to and staying in places outside their usual environment for not more than one consecutive year for leisure, business and other purposes. The basic tourism event is a program or activity performed by the tourism destination authority to attract visitors either from domestic or international for profit. (Mc Cartney, 2010:68)

Tour de Flores is classified as sport tourism event. It refers to a person or group actively or passively involved in a sport competition or a pleasure sport and willing to go and stay in certain place out of their residence. (Gammon \& Robinson, 2003). The impacts of an event, either positive or negative, can influence destination or the place where the event is held and local community (McCartney, 2010). The direct impact that will be experienced by the local people are economic, social, and environmental impact. Deliarnov (2003:23), explains economy as one of the science branches that studies human behavior or groups in their efforts to meet their unlimited need with limited resources. While, according to Suratmo (2004:24) economy is the impact of the existing change in the environment as the result of human activities.

The term "social impact" in this research is referred to the local perspective on the quality of life by means of an event performed in the region and their point of view which are very influential in tourism development (Pearch:2004). Meanwhile, regarding with the environmental impacts, Richardson and Fluker (2004) states that the impacts are as the following:

1. The use of transportation

2. Tourism facilities development

3. Tourism industry operational

4. Wildlife habitat damage

TRJ Tourism Research Journal, Volume 1 (1), 2017 
The Impacts of Tour de Flores Event for Tourism Development in West Manggarai, Nusa Tenggara Timur

5. Pollution and waste,

In line with Richardson and Fluker, Allen (2010) also states that the environmental impact is the change of natural resources such as sea, lake, water fall, and the beautiful scenery.

\section{Research Methodology}

The research methodology is quantitative descriptive with a multiple linear regression analysis and it was processed with SPSS 20. The sample is the residents of Labuan Bajo. Slovin formula is applied to determine the number of sample. With this formula, 100 participants take part from random sampling . The independent variables are economy, social, environment while the dependent variable is tourism development. Multiple linear regression is to find out whether the independent variables have positive influence om dependent variable. Questionnaires and interview are employed for the primary data collection.

\section{Result and Discussion}

\section{Result and Partial Hypothesis Explanation}

Based on the data processing on the gradation respond of the West Manggaraian people on research variable, the details are as follows:

1. H1: Is there any economic impact of TDF on tourism development in West Manggarai?

The first hypothesis on the economic impact on tourism development of West Manggarai is proved. It can be seen in score of $t$ count $>t$ table $(3,209$ $>1,985)$. In this case, the positive value of $t$ count means that the tourism development has a positive impact on economy.

The direct impact of the TDF on economy is the increasing number of occupancy rate from the accommodation business such as hotel and homestay. The interview with homestay owners state that the room occupancy increased up to $50 \%$ higher than that of the previous year. This is due to the tourists' preference to stay in a more affordable accommodation. The hotel cost is around $\mathrm{Rp} 500.000$ to $\mathrm{Rp} 850.000$ per night while in home stay the cost goes around Rp 200.000 to Rp 350.000. Besides the room occupancy, increased revenue is seen from catering business. Previously it cost is from Rp 700.000 to $\mathrm{Rp} 1.000 .000$ per day, now it goes up from $\mathrm{Rp}$ 1.000.000 to $\mathrm{Rp} 1.500 .000$. The souvenirs businessmen of local products also experience significant sales increase.

The data from airport authority in the midst 2016 confirmed an increase of tourist visit up to 83.712 compared to 2015 with only 61.257 visits. The 
The Impacts of Tour de Flores Event for Tourism Development in West Manggarai, Nusa Tenggara Timur

increasing number of tourist visits has motivated all the stakeholder to boost tourism development in West Manggarai. For example, the government has built new infrastructure to ease accessibility to tourist destination. Besides, construction workers are working to maintain the road facilities. Besides building and maintaining transportation infrastructures, the government has also provided sufficient water source facility. A more important aspect that is provided by the local government is the provision of $3 \mathrm{G}$ and $4 \mathrm{G}$ network connection in the area. In addition, the local government is planning to build a harbor by the end of the year to facilitate tourist visits.

The positive impacts of sport tourism are in line with a research conducted by Hritz (2010). The research further states that the sport event held in Indianapolis has significant economic and social impact, and it simultaneously boosts the tourism development. As for this research, the result can be taken as an evaluation for the government and local residents to prepare for the next event in 2017.

\section{Coefficients $^{\mathrm{a}}$}

\begin{tabular}{|l|l|l|}
\hline Model & t & Sig \\
\hline (Constant) & 5.673 & .000 \\
\hline Economic Impact (X1) & 3.209 & .002 \\
\hline Social Impact (X2) & .314 & .754 \\
\hline Environment Impact (X3) & 2.449 & .016 \\
\hline
\end{tabular}

a. Dependent Variable: Tourism Development $(\mathrm{Y})$ Sources: Result of SPSS data, 2017

2. H2: Is there any social impact of TDF on tourism development in West Manggarai?

The second hypothesis is not proved. The data processing shows that score $t$ count $<t$ table $(0,314<1,985)$ which means Ho is accepted. It can be concluded that TDF does not have an effect on social field.

The percentage contribution $3,1 \%$ is very small compared with other independent variables. Similar research result is also obtained by Saleh et al (2014). The local people consider that the cultural heritages are less introduced to the tourists. In fact, the cultural shows are only performed in certain events. To accommodate this tourism potential, the government has created a program called "Friday culture". This event, performed at Komodo International Airport, introduces cultural heritage attractions to visitors. Therefore, any visitor landing at Komodo airport on Fridays will see cultural attractions from the local people.

TDF can also serves as a means to promote cultural tourism with involving local residents. In relation to this, Pourmad (2011) has conducted a research on the impact of sport event in Iran. The result shows that the sport event has a social impact since cultural ceremonies were integrated in 
The Impacts of Tour de Flores Event for Tourism Development in West Manggarai, Nusa Tenggara Timur

the event and it symbolizes the local culture. In other words, such cultural ceremonies are to promote local culture to public (tourists and the participants of TDF).

3. H3: Is there any environmental impact of TDF on tourism development in West Manggarai?

From the data processing, it can be seen on $t$ count $>t$ table $(2,449>1,985)$, then $\mathrm{Ho}_{\mathrm{o}}$ is rejected, it means that the environmental impact is partially positive for the development of tourism in West Manggarai with contribution margin of $29.9 \%$.

The result clearly states that TDF has a positive impact on environment towards the development of tourism. The activities to keep the environment range from the preserving natural environment, historical buildings, to the provision of tourism center, and city parks for local residents and visitors.

\section{Result and Hypothesis Simultaneously}

Based on the table, it is obtained adjusted R2 value of $0.722(72.2 \%)$. This shows that the percentage contribution of independent variable influence (economic, social, and environmental impact) to tourism development variable is $72,2 \%$, and the rest is explained by other variable not included in this research model.

Model Summary ${ }^{b}$

\begin{tabular}{|c|c|c|c|c|}
\hline Model & $\mathbf{R}$ & R Square & $\begin{array}{c}\text { Adjusted R } \\
\text { Square }\end{array}$ & $\begin{array}{c}\text { Std. Error of the } \\
\text { Estimate }\end{array}$ \\
\hline 1 & $.885^{\mathrm{a}}$ & .730 & .722 & 1.208 \\
\hline
\end{tabular}

a. Predictors: (constant), Environmental Impacts (X3), Social Impacts (X2), Economic Impacts (X1)

b. Dependent Variable: Tourism Development $(\mathrm{Y})$

Sources: Result of SPSS data, 2017

\section{E. Conclusion}

Based on the given analysis, it can be summarized that Tour de Flores held in 2016 generally has a positive impact on the development of tourism in Flores, especially West Manggarai. The positive impacts are very rewarding regarding the government's efforts to make this event successful. This event is able to increase the number of tourist visits as well as the income of the area. In short, it is a long-term investment to promote Flores and tourism in Flores, especially West Manggarai internationally. This is essential since most foreign tourists are only familiar with komodo as one of the seventh wonders, but they have little 
The Impacts of Tour de Flores Event for Tourism Development in West Manggarai, Nusa Tenggara Timur

knowledge on natural and unique cultural attractions of the area. Moreover, the mountainous topography of Flores is a perfect location for the cycling event. With all of the above attarctions, it is expected that all 2016 TDF participants have unforgettable experience and best impressions that will encourage them join the next event. Despite some minor evaluations on the program, the successful completion of the program should be highlighted. Moreover, the local residents have experience the direct impacts on several aspects as revealed on this research.

All negative feedbacks on the management of the event serve as positive inputs for both the government and event organizers in order to improve the next event. It is badly expected that this event has a competitive advantage towards other similar events such as Tour de Ijen and Tour de Singkarak. Eventually, tourism in West Manggarai and Flores can benefit a lot from the organization of this event.

\section{F. Acknowledgement}

The completion of this researchs would not have been possible without the kind support and assistance of others that cannot be mentioned individually. We would like to extend our sincere thanks to all of them. We are highly indebted to Dr. Agustinus Sri Wahyudi and Dr. Chondro Suryono, for their guidance and constant supervision. We would also like to express our gratitude towards our parents \& family members for their kind cooperation and encouragement which help us in completion of this research. Our thanks and appreciations also go to the people who are directly or indirectly helped us out in developing the research. Bapak Jamal dan IGP team, Ibu Deth Berybe and everyone who has involved in any steps of this research. Thank you

\section{REFERENCES}

Allen, (2010). The impact tourism. Sea Grant Minnesota

Ardehay. (2010). Economic Impact of Tourism Industy. International of business and management.

Alhusin, S. (2003), "Aplikasi Statistik Praktis dengan Menggunakan SPSS 10for

Wi ndows", Edisi Kedua, Yogyakarta: Graha Ilmu. Hal: 69, 257, 341.

Economic melalui http://www.businessdictionary.com/

Etiosa. (2012). The Impact of Event On Host Community (The city of Pietarsari). Technologi of Bussines.

Ghazali, I. (2016). Aplikasi Analisis Multivariat Dengan Program IBM SPSS 23, Cetakan kedelapan, Universitas Diponegoro, Semarang. Hal 5, 103, 134, 138, $156,157$.

TRJ Tourism Research Journal, Volume 1 (1), 2017 
The Impacts of Tour de Flores Event for Tourism Development in West Manggarai, Nusa Tenggara Timur

Hritz \& Ross. (2010). The Perceived Impact of Sport Tourism : An Urban Host Community Perspective (Indianapolis, United States). Journal of Sport Management.24, 119 - 138

Haley, J.A. (2004). The Social Impact of Tourism (United Kingdom).Journal Management.29006

Hermantoro. (2015). Kepariwisataan Destinasi Pariwisata Produk pariwisata. Jakarta : Penerbit CV ADITRI

Jones. (2006). The Perceived Sosial Impact Of The 2006 Football World Cup (Munich). Journal of Service Management. 6548

Kaplanidou, K \& Vogt, Studying sport tourism event and destination images on intent to travel

McCartney, (2010). Event Management and ASIAN perspective. Singapore : The McGraw.Hill Companies

Mbaiwa. (2002). The Socio _ Economic and Enviroment Impact of Tourism Development on The Okavango Delta (North - Wester Botswana). The Journal Of Arit Environments. 54. 447-556

Ottevanger, H. J. (2007). Sport tourism: Factors Of Influence On Sport Event Visit

Motivation. Master of Arts in European Tourism management

Bournemouth University (UK)

Pourmand. (2010). The impact of archery Event on Tourism Development.Journal of Sport Management.

Pitana. (2009). Pengantar Ilmu Pariwisata. Yogyakarta: ANDI Yogyakarta

Priyatno, D. (2013), “Mandiri Belajar Analisis Data Dengan SPSS”, Yogyakarta: Media Kom. Hal 9, 30, 40.

Priyatno, D. (2014), "SPSS 22 Pengolah Data Terpraktis", Edisi 1, Yogyakarta: ANDI. Hal: 94, 103, 106.

Publication Manual, (2010) "Publication manual of the American Psychological Association. Washington DC.

Seebaluck, V., Naidoo, P. \& Munhurrun, P.R. (2015). Prospect and challenges of business tourism: a case of Mauritius : Review of business and finance studies, 6 (3): 45-55.

Standeven, J. \& De Knop, P. (1999). Sport Tourism. Leeds : Human Kinetics.

Sugiyono. (2007). Metode Penelitian. Bandung: CV Alfabeta

Sugiyono. (2014). Metode Penelitian Kuantitatif dan Kualitatif dan R \& D. Bandung : CV Alfabeta

Sugiarto. (2015). Metode Statistika Bisnis. PT Matana Publishing Utama

Santoso, S. (2013). Menguasai SPSS 21 di Era Informasi. PT.ELEK Media Komputindo. Jakarta. Hal: 347, 354

Whitfield. J.L. (2012). Attracting Convention and Exbibition Attendance to Complex Mice Venues : Emerging Data from Macao : International journal of tourism research. 
The Impacts of Tour de Flores Event for Tourism Development in West Manggarai, Nusa Tenggara Timur

Weed, M. (2006). Sport tourism and the Development of Sports Events : Department of Sport Science, Tourism \& leisure Canterbury Christy Church University, UK(13.12)

Zaei. (2013). The Impact of Tourism Indusrty on Host Community (New Delhi India). European Journal Hospitality and Rsearch. Pp 12 - 21 